\title{
Overreaction to non noxious vascular stimuli in migraine and effect of NMDA receptor blockade
}

\author{
M Nicolodi
}

From The European Headache and Migraine Trust International Congress

London, UK. 20-23 September 2012

In '94 we enlighten vascular hyperalgesia/allodynia in migraine $(\mathrm{M})$ sufferers [1]. Central pain is defined as "spontaneous pain and painful overreaction to stimulation". Delayed painful sensation was also described in so called hyperpathia following partial lesions in the CNS. The aim was to stress possible overreaction and its NMDA antagonists blockade after non noxious stimulation of vein walls induced as elsewhere described. Procedure: a sharp stretch of vein walls, innocuous in controls, was induced in $M$ sufferers. Delayed overreaction might be reported and scored on a 0-10 VAS in $189 \mathrm{M}$ sufferers (101 females, 88 males, mean age $32.5+3.8 \mathrm{SD}$ ) reporting 6-10 attacks A3 /month. It was planned to administer ketamine, specific non competitive antagonist at NMDA receptor sites, to $M$ sufferers to observe possible overreaction. Tested $\mathrm{M}$ sufferers reported delayed overreaction ranging from 3 to 8 on a $0-10$ VAS (mean $4.5+1.5 \mathrm{SD}$ ). Delayed overreaction lasted from $5 \mathrm{~min}$ to $4320 \mathrm{~min}$, mean $210.22 \mathrm{~min}+623$ SD . The majority of sufferers reported overreaction till to 25 min after application of the stimulus revealing their visceral/vascular hyperalgesia/allodynia, 5 reported overreaction lasting $4320 \mathrm{~min}$ and 6 were ailed by overreaction for 5 mins. The duration of overreaction was directely related to the severity/ frequency of headache attacks. ANOVA failed in evidencing sex or $M$ duration relationship, whereas a modest significativity $(p>0.02)$ was related to high scores in Wang and Zung tests (cut off $=40$ ). Ten days later the same stimulus was applied after 0,1 $\mathrm{mg} / \mathrm{Kg} /$ i.m. administration of ketamine, after a 3 days wash-out period. Patients reported neither allodynia/hyperalgesia or overreaction. The experience indicated the occurrence of overreaction in $\mathrm{M}$. The partial deafferentation condition was inhibited by using a sub-anesthetic dose

Foundation Prevention and Therapy Primary Pain, Italy of ketamine. Thus, the drug likely acted by altering process of neural deafferentation-like related discharge.

Published: 21 February 2013

Reference

1. Nicolodi M, Sicuteri R, Coppola G, Greco E, Sicuteri F: Visceral pain threshold is deeply lowered far from the head in migraine. Headache 1994, 34:12-19.

doi:10.1186/1129-2377-14-S1-P111

Cite this article as: Nicolodi: Overreaction to non noxious vascular stimuli in migraine and effect of NMDA receptor blockade. The Journal of Headache and Pain 2013 14(Suppl 1):P111.
Submit your manuscript to a SpringerOpen ${ }^{\circ}$ journal and benefit from:

- Convenient online submission

- Rigorous peer review

- Immediate publication on acceptance

- Open access: articles freely available online

- High visibility within the field

Retaining the copyright to your article 